\title{
Community Empowerment in Micro Enterprises For Sustainable Development in Wajo South Sulawesi Indonesia
}

\author{
Muhammad Guntur* \\ Departemen of State Administration \\ Faculty of Social Science \\ Universitas Negeri Makassar \\ Makassar, Indonesia \\ m.guntur@unm.ac.id
}

\author{
Andi Cudai Nur \\ Departemen of State Administration \\ Faculty of Social Science \\ Universitas Negeri Makassar \\ Makassar, Indonesia \\ cudainur@gmail.com
}

\author{
Aslinda \\ Departemen of State Administration \\ Faculty of Social Science \\ Universitas Negeri Makassar \\ Makassar, Indonesia \\ aslinda@unm.ac.id
}

\begin{abstract}
This study analyzes the operational programs implemented at the operational level of local government levels through the cooperative and SME Wajo, through Local Regulation Wajo No. 6 of 2008 regulating the Working Procedures Organization Department of the Regional Government of Wajo. This research use descriptive qualitative method, namely to identify the associated profile of service and performance of Cooperatives and SMEs Wajo and analyze the various problems faced by SMEs by using SWOT analysis then formulate a model of the implementation strategy of community empowerment in SMEs, particularly microenterprises in Wajo, Community empowerment in SMEs in Wajo still facing obstacles, namely the problems of low capital or limited skills of human resources and product marketing factor is still a problem to be solved. Based on the results of SWOT analysis (Strength, Weakness, Opportunity, and Treaths), it can be seen that the results of the formulation on the strategy of development of SMEs, especially microenterprises in Wajo has great opportunities for development and organization in its present condition and future, so it is possible to continues to expand, increase growth and achieve maximum progress.
\end{abstract}

Keywords: Community Empowerment, Micro Enterprises

\section{INTRODUCTION}

Based on the institution of Cooperatives, SMEs in South Sulawesi as the operational level, there are various fields that deal with community development programs in microenterprises among others concerning the growth of the business climate. The government's efforts in this regard the Department of Cooperatives, SMEs Industry and Commerce in carrying out the program of growing the business climate is making policy in order to provide convenience for microentrepreneurs in operation. Aspects growth becomes the main foundation of the business climate for micro entrepreneurs develop their business activities. Business climate could be favorable if the government took the role to build infrastructures that can be utilized by micro entrepreneurs, facilitating the financing of micro enterprises to obtain capital, the business information provided, the business licensing that does not burden the micro entrepreneurs so easy to obtain business opportunities, and governments to promote the -the micro businesses and supported by the institutions involved in the growth of the business climate.
Coaching aspect in the development of micro enterprises is also a community empowerment program in micro enterprises by the dynasty of Cooperatives and SMEs in South Sulawesi covering aspects; production and processing, marketing, human resources skills enhancement, design and technology. Fostering of micro-enterprises are formulated in a development patterns that can empower communities and encourage an increase in the capacity of micro-enterprises. Such as providing guidance and services through education and training to the community such as micro entrepreneurs in accordance with the interests of their respective business activities managed.

Micro-businesses also need a working partnership that is mutually beneficial to the principle of interdependence, trust, strengthen, and each raise between micro and medium businesses as well as in the areas of transfer of skills, marketing, financing, human resources and technology, so expect a micro-enterprise is able to develop its activities trying to be a strong and independent businesses in accordance with the expectations of Act No. 20 of 2008. with the ideal conditions by Hafsah explains that the implementation of the partnership is aimed at; increasing public revenue and micro businesses, increase added value for the acquisition of the partnership actors, increasing equality and empowerment of communities and microenterprises, promote economic growth in rural, regional and national, expanding employment opportunities, and improve national resilience [1]

The existence of micro enterprises an integral part of the national business world have accrued, potential and strategic role in realizing the development goals national. Given its role in development, micro-enterprise should be developed with the family spirit as the backbone of the national economy and largely Indonesian people live and depend on the micro business sector. Therefore, the government is obliged to direct, guide, protect and grow the business climate so that the entrepreneurial spirit of the people can be encouraged and motivated to carry out their business activities.

The United States is said to be the developed countries most of the economy is made up of micro-enterprises, although survive and development of micro enterprises in the United States due to the good policies through antimonopoly law against big business and economic freedoms 
maintenance of administrative arrangements for micro businesses [2], Based on the experience of other countries in the effort to empower micro, built in a container a very powerful organization to provide protection so that they remain a micro-enterprise businesses nationwide sustain business continuity.

For example, in Japan known as the "Federation of Credit Guarantee" was built in 1952, the institute aims to provide a guarantee fund for micro, in South Korea, known as "The Korean Credit garantee Fund" this institution was founded in 1976, aims to help micro, in Malaysia in 1972 established "credit guarantee Corporation Malaysia Berhad", aims to provide credit guarantees for SMEs, (4) in India began in 1971 known as the "Deposit Insurance and credit guarantee and (5) in the Philippines in 1983 formed sister institution, "The Guarantee Fund For Small and Medium Enterprise".In the United States known as "Small Business Administration". This institution, created in 1953 aims to help micro-enterprises to develop their business in terms of: the provision of licensing and administrative assistance, management, training and consulting and legal assistance [3]. Government efforts to empower communities in the micro businesses never ceases to make improvements in terms of policies, namely the issuance of a new Law No. 20 Year 2008 on Micro, Small and Medium Enterprises (MSMEs), With the legal basis regulating the micro enterprises will get the certainty and justice efforts through community empowerment of micro, like in other countries of micro enterprises commonly referred to as family businesses obtain legal protection of local government and are allowed to gain access related with the development of enterprises [4].

Community empowerment policy in micro business developed in line with the government policy theory proposed by Bromley, which divides into three tiers or levels, namely the policy level, organization level, and operational level. From Bromley policy process model can be explained that at the political level, there is a high state institution or agency authorized to issue regulations legislati (policies) on the widest scale, for example in the form of laws or government regulation[5].

The community empowerment program operated at the level of the operational level, the local government through the Department of Cooperatives and SMEs Wajo through Local Regulation Wajo No. 6 of 2008 regulating Organization Working Procedure of Department of Local Government Wajo including empowerment program by the Department of Cooperatives, SMEs, Industry and Trade. Therefore, this research focused on the operational level level that will analyze each part run or implement programs to empower SMEs. And more focused again on the empowerment of micro, although in Act No. 20 of 2008 includes the empowerment of micro and medium, or large.

Coaching aspect in the development of micro enterprises is also a micro-enterprise development program by the dynasty of Cooperatives and SMEs in South Sulawesi covering aspects; production and processing, marketing, human resources, design and technology. Fostering of microenterprises are formulated in a pattern of development which can empower and encourage the capacity building of micro enterprises. Such as providing guidance and services through education and training to microentrepreneurs in accordance with their respective interests managed business activities.
Micro-businesses also need a working partnership that is mutually beneficial to the principle of interdependence, trust, strengthen, and each raise between micro and medium businesses as well as in the areas of transfer of skills, marketing, financing, human resources and technology, so expect a micro-enterprise is able to develop its activities trying to be a strong and independent businesses in accordance with the expectations of Act No. 20 of 2008. with the ideal conditions by Hafsah explains that the implementation of the partnership is aimed at; increasing public revenue and micro businesses, increase added value for the acquisition of the partnership actors, increasing equality and empowerment of communities and microenterprises, promote economic growth in rural, regional and national, expanding employment opportunities, and improve national resilience [6].

In addition to the government and micro enterprises, the role of the banking sector is also very important with regard to all matters concerning funding, especially in terms of lending or banking policy determination. One of the activities of empowerment that is needed by microentrepreneurs are in the form of capital that can support their business turnover. One way to obtain capital through financing course, both financing through banks and non banks. To obtain the necessary financing requirements under the provisions applicable to each loan fund providers, such as; ability to prepare feasibility studies, the ability to apply for loans, and the availability of collateral. Sustainability of the micro-business community development is dependent upon the responsiveness of local governments to implement programs of activities relating to community empowerment of SMEs. However, efforts to achieve these expectations [7].

On the other hand, the barriers experienced by managed micro enterprises are weak link in efforts and market penetration of micro enterprises, which generally is a business unit of the family, have a business network is very limited and the ability to market penetration is low, plus the resulting product is very limited and has qualities that are less competitive. Limited facilities and infrastructure business, namely the lack of information relating to the progress of science and technology, leading to the facilities and infrastructure that they have also not rapidly developed and less support their growth as expected. Moreover, not infrequently micro enterprises difficulties in obtaining a strategic place due to the high rents. Limited access for SMEs in terms of access to information, a little more give effect to the competition of the products or services of the SME business unit with other products in terms of quality. The effect of this is the inability of the products and services as a result of SMEs to penetrate export markets.

This study analyzes the activities of community empowerment in micro enterprises in Wajo at the operational level level directly involved with the activities of microentrepreneurs, especially those engaged in the trade of small industries and services that have gained the promotion and development of the Department Koperasi and SMEs. This study also see further how the role of other institutions at the operational level institutional level directly involved in establishing micro-enterprises, such as banks, cooperatives, other non-governmental organizations.

In connection with community development activities by the government in this case the Department of Cooperatives and SMEs Wajo, expected an increase in 8 (eight) aspects, namely finance, infrastructure, information businesses, partnerships, Licensing business, business opportunities, 
promosi trade, and support institutional pursuant to Law No. 20 of 2008. SME Empowerment aside by the government also made by various companies and educational institutions, such as state/D, Chamber of Commerce, banks, NGOs and Community-Based Financial Institutions. But empowerment is done partially, so that there is no coordination, which in turn give rise to new problems, namely: (1) Decreased productivity, as a result of the focus on the development of SMEs and ignore short-term interests; (2) Operational inefficient, as a result of various types of operating fund expenditures that are not controlled properly; (3) The decrease in the quality, quantity and continuity, as a result of the operation is not a product quality assurance system, and continuous production, so many unsold production, which in turn supplies piled up; (4) Increased risk of losses, (5) Less provide social benefit, and (6) The decline in robustness and security of SMEs [8].

Empowering small business community in reference to the word empowerment, which is an attempt to actualize the potential that has been owned by the group of small entrepreneurs. Empowerment of small businesses is an effort to provide motivation/encouragement to employers so that they have the awareness and the ability to decide for themselves what they should do to cope with the problems they face.

The principle of empowerment of Micro, Small and Medium are: (1) growing independence, unity and entrepreneurship Micro, Small and Medium Enterprises to work at their own initiative, (2) the embodiment of public policy that is transparent, accountable and fair, (3) development based enterprises regional potential and marketoriented in accordance with the competencies that micro, small and medium enterprises, (4) improving the competitiveness of micro, small and medium enterprises, and (5) implementation of the planning, implementation and control in an integrated manner. Program Community empowerment in Business KECI: (a) Funding, (b) Facilities and infrastructure, (c) Information business, (d) a partnership, (e), licensing business, (f) business opportunities, (g) the promotion of trade, ( $\mathrm{h}$ ) institutional support, and (i) financing and underwriting and entrepreneurship development program which is a program to develop the soul and spirit of entrepreneurship and increase the competitiveness of small businesses [9].

This study uses a model of implementation of the policy of Donald S. Van Meter and Carl E. Van Horn in Subarsono, for this theory can be used as a reference to measure, describe and explain the Empowerment Program Implementation micro enterprises in Wajo. Based on this, the researchers describe the concept of a clear framework to be easily understood [10].

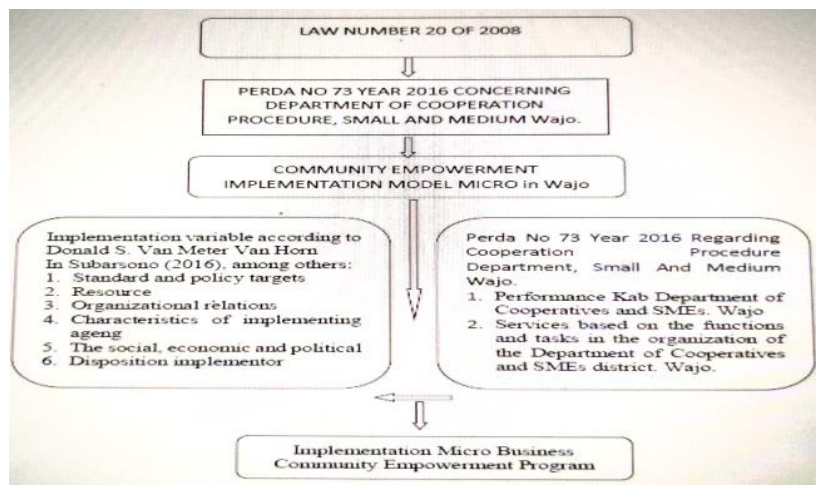

\section{METHOD}

In determining the location of research states the best way reached by considering the theory of substantive and exploring the field to seek conformity with the reality on the ground, while the limitations of geography and practical such as time, cost, effort needs to be taken into consideration in determining the location research [11]. This study took place in the District Tempe, District Tanasitolo, and the District Sabbangparu with the consideration that the three districts are populated more micro-entrepreneurs be compared to other districts, making it possible to perform more in-depth study will be widely available for comparison and data obtained. Other requirements were used as a reference in determining the informants in this study are micro-businesses that have been recorded and has received assistance from the Department of Cooperatives and SMEs in Wajo. Data analysis is the process of looking for sestematis compile data obtained from interviews, field remarks, and documentation. Analysis of the data used in this study is descriptive analysis is to describe the nature of things that took place at the time of the study [12].In this study aims to formulate a model of SMEs development strategy based on competitiveness. The analytical tool used in this research is descriptive analysis and SWOT analysis. Descriptive analysis is used to process the data collected in the form of primary and secondary data. This analysis aims to identify the problems and issues faced by SMEs, particularly micro-enterprises. Analysis using frequency tabulation assistance.

\section{RESULT AND DISCUSSION}

To assess, formulate technical policy guidance materials and the development of the empowerment and development of cooperatives. Community Empowerment and Cooperative Development has the following functions:

a) Preparation of technical policy in the field of Production Cooperative Business Development;

b) Monitoring, analysis, evaluation and reporting in the field of improving the quality of agricultural production, fisheries and animal husbandry, industry and services increase product standardization;

c) Business development Credit Unions (KSP), Business Savings and Loans (USP), Islamic Financial Service Cooperative (KJKS), Islamic Financial Services Business (UJKS)

d) Facilitate the implementation of financing through a guarantee institution for cooperatives KSP / USP and Cooperative Rural Banks;

e) Implementation Facilitation and Protection Strengthening Cooperative Business

f) Guidance, Control, Monitoring Programs and Activities Section and Acting Head of Non-Structural within the scope of the field; and

g) Implementation evaluation of programs and activities of the head section and the non-structural officials within the scope of the field.

Technical policy formulation and development of micro, small and medium enterprises which include production of marketing, human resources and technology through: 
a. Preparation and adoption of the policy of community empowerment and growth of the business climate for micro, small and medium enterprises that includes financing, provision of financial resources and the requisite procedures for fulfilling the needs of funds, infrastructure competition, and protection of business information;

b. Implementation assistance and data collection as well as $M \& E$ activities for SMEs;

c. Implementation guidance and technical guidance of SMEs;

d. Preparation of materials in order to promote cooperatives and SMEs;

e. Guidance, control, monitoring programs and activities section heads and officials of non-structural within the scope of the field;

f. Implementation evaluation of programs and activities of the head section and the non-structural officials within the scope of the field;

g. Implementation of other official duties that were ordered by superiors in accordance field of duty Existence Analysis of Micro In Wajo

The government's role in the development of SMEs, particularly micro-enterprises in the implementation of regional development is one absolute requirement in the era of regional autonomy. The government in this case is the Department of Cooperatives and SMEs have a role as it has been carried in their duties and functions.

Related strategy should the Micro ahead. There are at least three major factors that need attention, namely;

First, How to strengthen internal factors Micro, which has been menjad Micro, performance development constraints; second, how the role of government in addressing the external constraints that arising from the impact of globalization, and third, efforts need to be made by the government in improving the dynamic development of the Micro.

Therefore, government policies that lead to a market driven policy to support a conducive business climate is an arena of preparation for Micro Facing the Free Market. Authorized Develop Micro Enterprises face the free market is to create a conducive business climate, strengthen the competitiveness of micro businesses by increasing access to quality non-financial services and increase access to micro enterprises in the financial services. In the short term the development of Micro should diarah product development efforts that have special characteristics (niche product) to fill the market [13].

In the concept of competing in the global market, the people who have a wealth of intangible assets $3 \mathrm{C}$ that concept, competence and conection had the better chances, while the Micro tend only with a zest for life and minimal strategy, here need the government's role to push the Micro actively improve competitiveness. In this case Osborne and Gaebler put forward 10 principles to produce high quality public goods and services, namely:

1. Steering rather than rowing (Better government as a driver of the scull);

2. Empower Reviews their own communities to solve problems, rather than Merely deliver services
(Empowering Micro, in solving the problem rather than providing services);

3. Promote and encourage competition rather than monopolies (Creating competition within each ministry);

4. Be driven by missions rather than the rule (Emphasis to the mission rather than the rule);

5. Result oriented by funding outcomes, rather than outputs (Orientation to perform well not just achieve output);

6. Meet the needs of the customer rather Reviews those of the bureaucracy (Giving priority to meeting the needs of micro, not the needs of bureaucrats);

7. Concentrate on earning money rather than just spending it (The cost savings in each program instead of spending);

8. Invest in Preventing problems rather than curing crisis (prevention is better than cure);

9. Decentralize authority rather than build hierarchial (required decentralization of authority, rather than build hierarchial.

10. Solve the problem by Influencing market forces rather than by treating public programs (the Government should pay attention to market demand, the supply must be adapted to the needs of the market).

Another step that needs to be done is to identify market opportunities through the development of network marketing, such as through the method of market penetration, market expansion, product development and diversification. Selection of this method is of course to be adapted to the competitive advantage of products for small businesses. For businesses including micro businesses mencemati free market from two sides of the opportunities and challenges. Increasing competitiveness reached by synergizing the government's role as manager of the bureaucracy to the role of micro-enterprises as a business manager. Increasing competitiveness associated with the high cost or in the context of efficiency, the role of government for example to simplify the permitting both costs and requirements and type, promotion because it is difficult for micro businesses as it requires a high cost, look for regional micro business that specialized in selling products micro-enterprises as a global tourist destination as well as facilitate partnerships with mutually beneficial format. One of them is considered quite successful in many countries and should receive government support is a pattern of subcontract [14].

Subcontract good pattern will be a positive impact in improving the efficiency of both macro national efficiency, as well as micro-efficiency of the company; strengthening the national economic structure and realize economic democracy [15]. Some of the issues that need attention in the development of subcontracting patterns that the business climate; empowerment subcontractors (Micro), the feasibility of the transaction and associated subcontracts.

\section{CONCLUSION}

Community empowerment in MSMEs in Wajo Regency still faces obstacles, which are related to capital problems that are still limited, as well as the lack of professionally educated human resources in terms of skill ownership, and 
product marketing factors that are still limited in cooperation networks are problems that solutions must be sought for solutions to. Based on the results of the SWOT analysis (Strength, Weakness, Opportunity, and Treatments), it can be seen that the results of the formulation related to the MSME development strategy, especially microbusinesses in Wajo District, have a great opportunity to be developed through organized management that is modern in order to continue to exist in present and current conditions. will come, so it is possible to continue to expand expansion, enlarge revenue growth and achieve maximum success. For MSMEs, Wajo Regency should always maintain the stabilization of the business both from the use of raw materials, the provision of skilled labor, a broader marketing system, labor reliability to the involvement of government bureaucracy that continues to support small and medium businesses through comprehensive coaching, improving the quality of internal management and external and also minimize external and internal obstacles that are considered to interfere with the operational activities of MSMEs in Wajo Regency by providing a system of supervision, supervisory discipline, obeying the principles and supported by facilities and infrastructure to complement production equipment.

Community empowerment in MSMEs in Wajo District can be successful if it has the support and role of the government in terms of quality services and maximum performance improvement by the Office of Cooperatives and MSMEs in Wajo Regency and the cooperation of more priority stakeholders in providing guidance and assistance to micro entrepreneurs, so more comprehensive carrying capacity is needed, especially in terms of increasing capital, technology-based marketing, and the use of information technology in a variety of activities and improving production quality.

The priorities of the government and related institutions are very supportive and provide broad opportunities in the development of MSME businesses in Wajo district both in terms of providing education and training, providing maximum facilities and infrastructure as well as providing information and technology that supports the improvement of the success of MSMEs in Wajo Regency.

\section{ACKNOWLEDGMENT}

Special appreciation also given to all informants who are faithfully sharing valuable information to us so that all data needed in the research can be collected.

\section{REFERENCES}

[1] M. Milsa, “Tinjauan Yuridis Perjanjian Pola Kemitraan Perkebunan Kelapa Sawit Inti-Plasma Antara PT. Boswa Megalopolis Dengan Masyarakat (Suatu Penelitian Di Kabupaten Aceh Jaya)," Premise Law J., vol. 4, p. 14102, 2015.

[2] S. Soetriono, D. Soejono, D. B. Zahrosa, A. D. Maharani, and R. Hanafie, "Strategy and policy for strengthening the agricultural cooperative business in East Java, Indonesia," J. Socioecon. Dev., vol. 2, no. 1, pp. 12-22, 2019.

[3] J. G. Longenecker, J. W. Petty, L. E. Palich, and F. Hoy, Small business management. Nelson Education, 2013.

[4] R. A. E. Wahyuni and D. Hartono, "Implementation Of Legal Protection By The Government In Order To
Empowerment Of Micro Small Medium Enterprise To Realize The Justice Economy (Research Study: The Office of Cooperative and Micro Small and Medium Enterprise Province of Central Java)," Diponegoro law Rev., vol. 4, no. 1, pp. 388-396, 2019.

[5] P. Bromley, "The rationalization of educational development: Scientific activity among international nongovernmental organizations," Comp. Educ. Rev., vol. 54, no. 4, pp. 577-601, 2010.

[6] G. S. Ogato, "The quest for gender equality and womens empowerment in least developed countries: Policy and strategy implications for achieving millennium development goals in Ethiopia," Int. J. Sociol. Anthropol., vol. 5, no. 9, pp. 358-372, 2013.

[7] W. Kumorotomo, Desentralisasi fiskal: politik dan perubahan kebijakan, 1974-2004. Kencana Prenada Media Group, 2008.

[8] J.-C. Yang, "The efficiency of SMEs in the global market: Measuring the Korean performance," $J$. Policy Model., vol. 28, no. 8, pp. 861-876, 2006.

[9] J. Jacob and I. Susilowati, "Implementation Of Good Governance Principles In Public Procurement For Empowerment Of Micro Small Enterprise: Empirica Study In Bitung City North Sulawesi Province," Int. J. Res., 2014.

[10] M. Guntur, A. C. Nur, and H. Zainal, "The Implementation Model of Policy for Small Business Empowerment Programs in Wajo Regency, Indonesia," in 1st International Conference on Education Social Sciences and Humanities (ICESSHum 2019), 2019.

[11] J. Moeloeng, "Lexi. Metode Penelitian Kualitatif Edisi Revisi.” Bandung: Rosdakarya, 2007.

[12] P. Sugiyono, "Metodologi penelitian kuantitatif kualitatif dan R\&D," Alpabeta, Bandung, 2011.

[13] J. C. Ling, B. A. K. Franklin, J. F. Lindsteadt, and S. A. N. Gearon, "Social marketing: its place in public health," Annu. Rev. Public Health, vol. 13, no. 1, pp. 341-362, 1992.

[14] C. Mambula, "Perceptions of SME growth constraints in Nigeria," J. small Bus. Manag., vol. 40, no. 1, pp. 58-65, 2002.

[15] M. Storper, "Society, community, and economic development," Stud. Comp. Int. Dev., vol. 39, no. 4, pp. 30-57, 2005. 